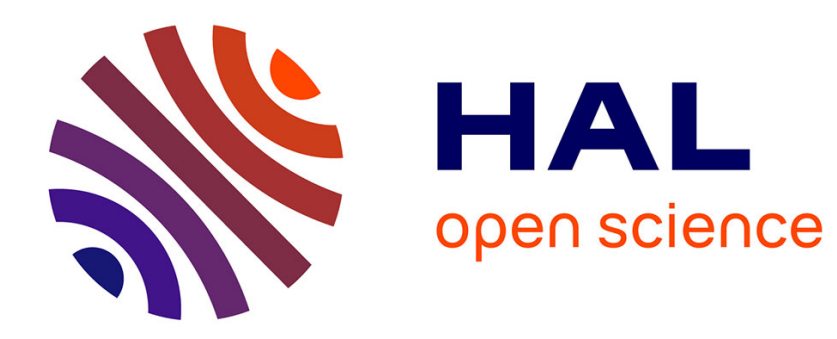

\title{
Growth studies of laser-induced CVD diamond films
} W. Luo, P. Ren, Z. Tan

\section{To cite this version:}

W. Luo, P. Ren, Z. Tan. Growth studies of laser-induced CVD diamond films. Journal de Physique IV Proceedings, 1993, 03 (C3), pp.C3-281-C3-284. 10.1051/jp4:1993338 . jpa-00251395

\section{HAL Id: jpa-00251395 https://hal.science/jpa-00251395}

Submitted on 1 Jan 1993

HAL is a multi-disciplinary open access archive for the deposit and dissemination of scientific research documents, whether they are published or not. The documents may come from teaching and research institutions in France or abroad, or from public or private research centers.
L'archive ouverte pluridisciplinaire HAL, est destinée au dépôt et à la diffusion de documents scientifiques de niveau recherche, publiés ou non, émanant des établissements d'enseignement et de recherche français ou étrangers, des laboratoires publics ou privés. 


\title{
Growth studies of laser-induced CVD diamond films
}

\author{
W. LUO, P. REN and Z. TAN
}

Center for Functional Materials Research, Qingdao Institute of Chemical Technology, Qingdao 266042, P.R. China

\begin{abstract}
The growth of laser-induced chemical vapour deposition diamond thin films are studied. The X-ray diffraction (XRD) and electron diffraction analysis showed the structure of these film layers change from an amorphous to polycrystaline is obtained on scratched silicon substrate and at different growth conditions. The process of growth and structure of these films have been discussed.
\end{abstract}

\section{I - INTRODUCTION}

Diamond has superior properties for example great hardness, high thermal conductivity, chemical inertness, high stiffness, high carrier mobilities etc. Diamond coatings and films have been prepared from the rapor phase at low pressure. These preparation techniques have been developed include chemical rapor deposition (CVD) [1], i on beam techniques [2], plasma induced deposition [3], microware plasma deposition[4] and variations or hybrids of these. Laser induced CVD seems to proceed through a mechanism quite different from that of other methods [5]. In the paper, we report the growth condition and structure of laser induced-CVD of diamond films. It is shown that the polyerystalline diamond films wh good crystallinity are obtained on roughened $\langle 111\rangle$ silicon substrate. The experiment indicates these films are more uniform and the growth temperature is lower than using conventional methods [6].

\section{II - EXPERIMENTS}

The diagram of experimental set-up for laser-induced CVD diamond film is shown in Fig. 1. The reaction is carried out by use of methane diluted with $\mathrm{H}_{2}\left(\mathrm{CH}_{4}\right.$ concentration $1 \%)$ as a source gas $\left(\mathrm{H}_{2}+\mathrm{CH}_{4}\right)$ at 10 pressure. The smooth substrate surface of (111) silicon is scratched and roughened to facilitate nucleation before growth beginning. The substrate is kept at a temperature of $60-700^{\circ} \mathrm{C}$. In experiment the ir radiation of focused two laser beams $(\lambda=266 \mathrm{~nm})$ are separately against and parallel from the substrate (Fig. 1), the power density on the substrate is $60 \mathrm{~mJ} / \mathrm{cm}^{2}$ pulse. 
The samples of diamond films are detected by the X-ray diffraction(XRD), high energy electron diffraction (RHEED) and scanning electron microscopy (SEM). These results are given in Fig. 3-3-4.

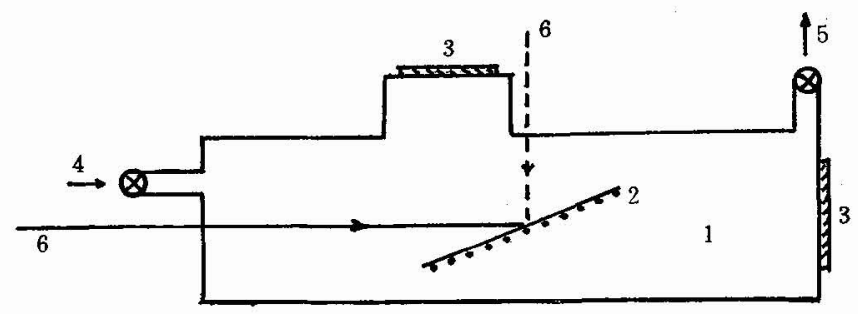

Fig. 1 Diagram of experimental set-up
1. reactor
2. substrate
3. window
4. source gas
5. pump ing
6. Laser beam

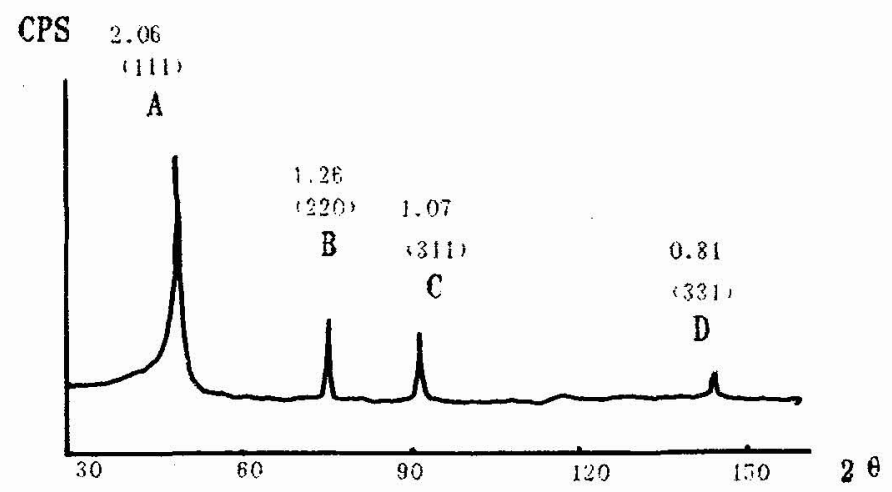

Fig. 2 XRD for diamond film (substrate temperature $420^{\circ} \mathrm{C}$ )

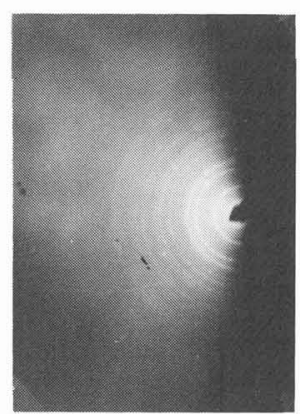

(a) at $420^{\circ} \mathrm{C}$ growth Fig. 3 RHEED patterns of diamond films

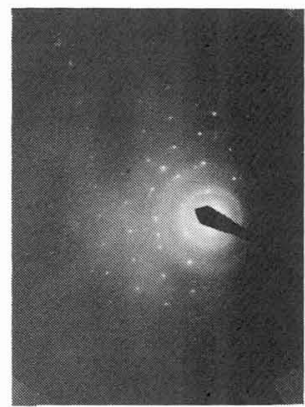

(c) at $620^{\circ} \mathrm{C}$ growth 


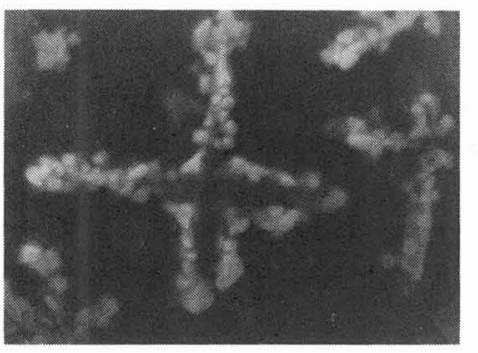

(a) on scratched silicon substrate

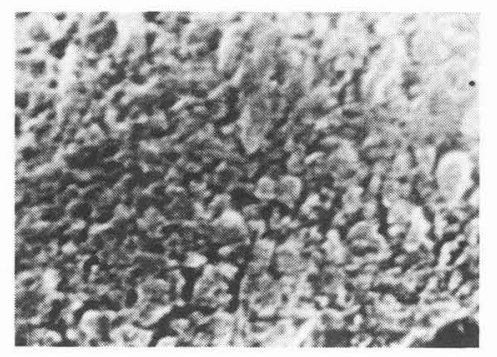

(b) on rough silicon substrate

Fig. 4 SEM patterns of diamond films (X5. OOK)

\section{III - RESULTS}

It is shown that the laser induced-CVD would appear to be effectire in lowering the reaction temperature $\left(420^{\circ} \mathrm{C}\right)$. The XRD shows in good agreement with the values reported for cubic diamond (Fig. 2). A typical RHEED photograph of diamond film, which is prepared at $420^{\circ} \mathrm{C}$, shows that all diffraction lines belong to diamond (Fig. $3(\mathrm{a})$ ). Irrespective of deposition temperature, a few RED photographs show that the coexistence of graphite and SiC (Fig. 3 (b). (c)). The XRD. RHEED and SEM analysis show that the structure of the film layers changes from amorphous to polycrystaline on (111) silicon substrate, in different growth conditions (Fig. 3 and Fig. 4). A SEM photograph of the same sample is shown in Fig.4. Particles which do not show clear shape with diameters $\sim 0.5 \mu \mathrm{m}$ grow along the edge of the scratch lines, as is observed in experiment (Fig. $4(\mathrm{a})$ ). The diamond films, which obtained by laser induced-CVD technique on the rough silicon substrates, possess uniform structure feature (Fig. 4 (b)).

\section{V -DISCUSSION}

The decomposition of $\mathrm{CH}_{4}$ and $\mathrm{H}_{2}$ by laser induced mainly occurs at the substrate surface, because the scanning double laser beams seact to substrate surface and source gas respectively for produced hydrogen atoms and activated intermediates. The hydrogen atoms play an important role in the growth mechanism of diamond. Methyl radicals and other activated radicals are also important. If these radicals could be produced at high density and supplied to the substrate, diamonds would be formed with high growth rates. Diamond is formed when the power density of the focused laser beam appears to be enough to yield activated radicals by way of multipe photon process. A few RED photographs show the coexistence of graphite and SiC (Fig. 3 (b) (c)), because on a silicon substrate the growth condition of $S i C$ by thermal diffusion of carbon into $S i$ is same as that of diamond. 


\section{$V$-CONCLUSION}

In the paper, the experiment indicates diamond can be formed by double focusing beams $(\lambda=266 \mathrm{~nm})$ Iaser-induced CVD technique. The experiment has also indicated that the optimal deposition conditions of diamond films growth. The polycrystalline diamond films are obtained at $420^{\circ}$. The suitable irradiation power density and irradiation geometry are important, because the growth process of diamond is a multiple photon process.

\section{REFERENCE}

[1] MATSUMOTO S., SATO Y., TSULSUMI M. and SETAKA N, J. Mater Sci, 17 (1982) 3106.

[2] MEISSMANTEL C. et a1., Thin Solid Films 72 (1980) 19.

[3] MOHRI T. and NAMBA Y., J.App 1. Phys. 55 (1984) 3276.

[4] SHING Y.H., POOL F.S. and RICH D.H., Thin Solid Films 212 (1992) vii,

[5] KATSUKI KITAHAMA et a l., App 1. Phys. Lett, 49 (1986) 634.

[6] KAZUAKI KURIHARA it a., App 1. Phys. Let t. 52 (1988) 437. 